\title{
Effect of Reference Conveyance Parameter Usage on Real Time Canal Performance: The Case of Fentale Irrigation Scheme in Ethiopia
}

\author{
Mebruk Mohammed ${ }^{1,2}$, Adam Tefera ${ }^{3}$ \\ ${ }^{1}$ Addis Ababa Institute of Technology, Addis Ababa University, Addis Ababa, Ethiopia \\ ${ }^{2}$ Federal Policy Study and Research Center, Addis Ababa, Ethiopia \\ ${ }^{3}$ Madawalabu University, Bale Robe, Ethiopia \\ Email:mima_moh@yahoo.com,mebruk.mohammed@aait.edu.et, adamdinsa@yahoo.com
}

How to cite this paper: Mohammed, M. and Tefera, A. (2017) Effect of Reference Conveyance Parameter Usage on Real Time Canal Performance: The Case of Fentale Irrigation Scheme in Ethiopia. Computational Water, Energy, and Environmental Engineering, 6, 79-88.

http://dx.doi.org/10.4236/cweee.2017.61006

Received: November 8, 2016

Accepted: December 27, 2016

Published: December 30, 2016

Copyright (c) 2017 by authors and Scientific Research Publishing Inc. This work is licensed under the Creative Commons Attribution International License (CC BY 4.0).

http://creativecommons.org/licenses/by/4.0/

\begin{abstract}
In designing a canal system, a major problem is to decide what conveyance parameter to apply in the calculations. Since basic knowledge on this subject is lacking, it is usually taken from literatures. Most of the irrigation projects in Ethiopia are found to work below their expectation. One of the main reasons is the conveyance parameters variation from the expected (design) value which ultimately affects the envisioned conveyance efficiency. To evaluate this variation, Fentale irrigation scheme was used as case study. The conveyance efficiency used at the design stage was $80 \%$, which was within Food and Agricultural Organization of the united nations recommendations; while the field survey value was $17 \%$. Such huge variation was due to the fact that the assigned conveyance parameter values (roughness coefficient, hydraulic radius and bed slope) no longer represent the current situation of the scheme. Such variation has resulted in increase in the depth and top width of the water surface which further resulted in $13 \%$ and $3 \%$ increase in wetted perimeter and top width of the canal, respectively. Thus this study suggests that conveyance parameters shall be derived from history of existing irrigation schemes in a country, rather than adopting it from standard literatures. As such construction quality, maintenance activities and technological transfer activities in a country shall be seen in deciding the conveyance parameters. The study also suggests that the ever increasing water shortage in an irrigation project could be managed by proper maintenance of the entire irrigation system.
\end{abstract}

\section{Keywords}

Conveyance Efficiency, Conveyance Parameters, Fentale Irrigation Scheme, Irrigation Canal Design

\section{Introduction}

Different irrigation schemes did not satisfy the net irrigation demand even though the 
available water is more than that, due to high losses from storage, conveyance, and application to irrigation plots. Identifying the various components with their level of losses and knowing what improvements can be made are essential in making most effective use of vital water resource. As available water resources become scarcer, more emphasis is given to efficient use of irrigation water for maximum economic return and water resources sustainability. This requires appropriate methods of measuring and evaluating how effectively water extracted from a water resource is used to produce crop yield [1], which intern shall start from the planning and design stage of an irrigation project.

In planning and designing a canal system, a major problem is to decide what conveyance parameters to apply in the calculations. Since basic knowledge on this subject is lacking, it is common practice that this efficiency is usually assumed. Obviously, the parameters thus obtained are unlikely to suit the conditions of the canal in its future state. Because conveyance parameters future state is usually the "guess" factor in the design of canal system, engineers are facing the problem of uncertainty in their calculations. Due to this uncertainty, canals and their appurtenant hydraulic structures are being given a greater or lower capacity than would be necessary. Apart from harmful side effects, this way of doing things leads to investments that may be considerably higher than would otherwise be necessary [2].

Stakeholders in Fentale Irrigation scheme complain that water stress is increasing from year to year as information obtained from staff members of supervisory bureaus. The same idea was supported by other studies ([3] [4] [5]). Water conveyance loss consists mainly of operation losses, evaporation and seepage into the soil from the sloping surfaces and bed of the canal. The most important of these is seepage. The seepage loss in the irrigation canals accounts for the major portion of water conveyance loss (98.37\%) while approximately 0.3 per cent of the total stream is lost due to evaporation [6]. Evaporation loss in irrigation networks is generally not taken into consideration [7] [8].

Seepage losses could be enhanced due to inappropriate conveyance parameter estimation which leads to smaller irrigation efficiency. Among the causes of irrigation inefficiency, conveyance efficiency is one of them. Main causes for low canal conveyance efficiency would be hydrologic, hydraulic and/or technological transfer. This research limits the hydrologic and hydraulic reasons as it would be hydrologic in the sense that the evaporation and seepage losses are under estimated. It would be hydraulic, if the designed hydraulic parameter values of the conveyance system might not reflect the real values. If the trained farmers in the water use association failed to operate the irrigation system, the effect of technological transfer in having low conveyance efficiency is an obvious consequence.

Appropriate value for conveyance parameters in planning and design will lead to improve equity in water distribution and minimize the gap between crop water requirement and actual water use. Therefore, the assessment of the potential cause of canal conveyance inefficiency is vital for sustainable functionality of irrigation schemes. Two main principal factors affecting conveyance efficiency (hydraulic and hydrologic factors) will be studied in this paper by taking a main canal as a case study. The envisioned (designed) and actual conveyance characters of the main canal in Fentale Irriga- 
tion scheme found in Awash Basin of Ethiopia will be assessed for possible hydraulic and hydrologic reasons of inefficiency.

\section{Materials and Method}

\subsection{Location of the Study Area}

In order to evaluate canal conveyance parameters, Fentale irrigation scheme in Awash River Basin was selected. Awash River basin, geographically located in the world's main rift system, covers a total area of $110,000 \mathrm{~km}^{2}$ and is by far the most utilized river basin of Ethiopia which lends itself for usual water shortage complaints [9]. Fentale Irrigation Scheme is found at a distance of $200 \mathrm{~km}$ the capital of Ethiopia, Addis Ababa. Generally, the project is in low land agro-ecological zone characterized by low annual precipitation $(\sim 500 \mathrm{~mm})$ and high temperature $\left(10^{\circ} \mathrm{C}\right.$ to $\left.38.3^{\circ} \mathrm{C}\right)$ and. It falls in between $8^{\circ} 50^{\prime} \mathrm{N}$ and $9^{\circ} 04^{\prime} \mathrm{N}$ latitude and $39^{\circ} 41^{\prime} \mathrm{E}$ and $39^{\circ} 52^{\prime} \mathrm{E}$ longitude, with altitude ranging from 970 to $1020 \mathrm{~m}$ above mean sea level. The headwork is at an elevation of $1050 \mathrm{~m}$ amsl [9].

The planned irrigation area is about 27,000 hectares (ha). Irrigation water for abstraction is raised by weir at the headwork of the project and conveyed through main canal of $49.3 \mathrm{~km}$ length and two Branch Canals (38 and $31 \mathrm{~km}$ length) with pertinent structures including Electro-mechanical equipment for Kawa command area [9] [10]. The whole canal system uses gravity driven flow except Kawa command area, which is irrigated by pump. Except the major conveyance canal, all the project distribution systems were subsurface pipes.

Fentale was designed and constructed to take maximum of $18 \mathrm{~m}^{3} / \mathrm{sec}$ of water from the river by Diversion Weir with conveyance efficiency of $83 \%$ (see Table 1 ). The diverted irrigation water is conveyed through the $49.3 \mathrm{~km}$ Main Canal. At $34.650 \mathrm{~km}$ a Branch Canal (BC-I) bifurcates towards the Haro-arbo area and the other Branch Canal-II (BC-II) going towards Galcha (North Block) after $49.3 \mathrm{~km}$. The designed discharge of branch Canal-I and Branch canal-II were $6.72 \mathrm{~m}^{3} / \mathrm{sec}$ and $6.0 \mathrm{~m}^{3} / \mathrm{sec}$ respectively [9] (Figure 1).

\subsection{Data Collection}

The first activity done was the reconnaissance survey in order to get the general insight of irrigation projects in the basin. During which water use associations, professional

Table 1. Computed and designed Ec at different locations along the main canal.

\begin{tabular}{ccccccccc}
\hline \multirow{2}{*}{ Location at } & \multicolumn{2}{c}{ Slope } & \multicolumn{2}{c}{ Manning's n } & \multicolumn{2}{c}{ Discharge } & \multicolumn{2}{c}{ Ec } \\
\cline { 2 - 9 } & Existing & Design & Existing & Design & Existing & Design & Existing & Design \\
\hline HR & 0.001 & 0.0012 & 0.049 & 0.02 & 4.351 & 18 & - & - \\
$17.52 \mathrm{~km}$ & 0.0012 & 0.001 & 0.073 & 0.03 & 3.355 & 17 & 0.77 & 0.94 \\
$26.9 \mathrm{~km}$ & 0.001 & 0.001 & 0.048 & 0.02 & 1.239 & 15 & 0.37 & 0.88 \\
$42.7 \mathrm{~km}$ & 0.0008 & 0.001 & 0.026 & 0.017 & $0.536+0.2^{* *}$ & $7.2+6.72^{*}$ & 0.59 & 0.93 \\
& \multicolumn{3}{c}{ Canal conveyance efficiency } & & $\mathbf{0 . 1 7}$ & $\mathbf{0 . 7 7}$ \\
\hline
\end{tabular}

${ }^{*}$ The discharge carried by branch canal (BC-I) located at $34^{\text {th }} \mathrm{km}$. ${ }^{*}$ The discharge observed in the branch canal I (BC-I) during the study time. 


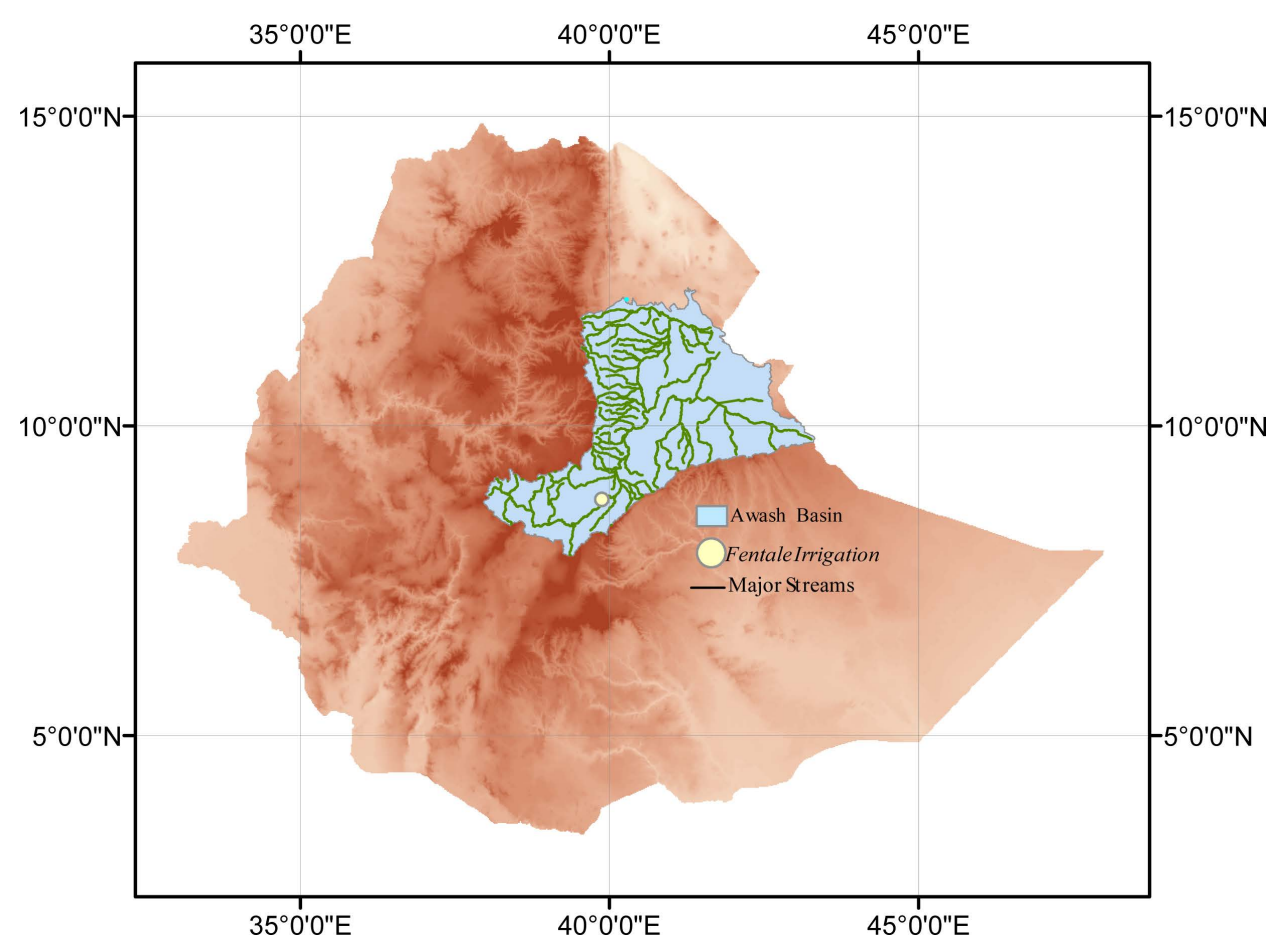

Figure 1. Location of the study area.

staffs and some farmers were consulted about water use practices, highlight of the status of the projects and inefficiencies encountered by different projects. Such consultation and reconnaissance survey results were used to identify the data type, location and time to collect these data. Frequent field observation at Fentale project was made to judge places where canal discharge measurement must be taken. After that, main canal discharge at carefully selected points of the project was taken by using the Current Meter in collaboration with the Hydrology Department of the Ministry of Water Resources and Energy of Ethiopia. With this Current meter, canal discharge was measured at different depths across the width of the canal. The discharge measured by this equipment was obtained by dividing the number of clicks by the duration in which the number of clicks was counted. To bring about high precision in measurement, the duration in which the number of clicks counted was made to be greater than forty seconds, which is in accordance with [11]. The points of measurement taken were at straight reaches of the canal. Besides the canal slope and cross-sectional survey was also conducted along and across the location where discharge measurement was taken. The discharge is measured through careful measurement of velocity, slope, wetted area and perimeter of the canal.

While measuring the velocity, the canal section was first divided in to $0.5 \mathrm{~m}-1 \mathrm{~m}$ interval cross-sectional lengths. Then on the basis of the existing depth of flow at each interval, velocities were measured at one or two depth locations. Such velocity data were collected at four locations (see Table 2) along the main canal of Fentale irrigation scheme.

Slope of the canal were measured through surveying the canal bed profile for $200 \mathrm{~m}$ upstream and $150 \mathrm{~m}$ downstream of the canal section at which the velocity is measured. Wetted area and perimeter were also obtained through careful survey of the canal cross section. 
Table 2. Observed data location naming and canal section description.

\begin{tabular}{|c|c|c|c|c|}
\hline Main canal reach & Designed Q $\left(\mathrm{m}^{3} / \mathrm{sec}\right)$ & Canal shape* & Canal-section taken at & Canal bed elevation ( $\mathrm{m}$ amsl) \\
\hline $\begin{array}{l}\text { From the head regulator } \\
\text { (HR) to about } 17.52 \mathrm{~km}\end{array}$ & 18 & Trapezoidal $1.5 \mathrm{H} \times 1 \mathrm{~V}$ and $1.0 \mathrm{H} \times 1.0 \mathrm{~V}$ & HR & 1050.0 \\
\hline From $17.52 \mathrm{~km}$ to $26.9 \mathrm{~km}$ & 17 & $\begin{array}{l}\text { (short distance for stretch covered } \\
\text { by sound rock) }\end{array}$ & $17.52 \mathrm{~km}$ & 1032.48 \\
\hline From $26.9 \mathrm{~km}$ to $42.7 \mathrm{~km}$ & 15 & & $26.9 \mathrm{~km}$ & 1023.1 \\
\hline From $42.7 \mathrm{~km}$ to $49.3 \mathrm{~km}$ & 7.2 & $\begin{array}{l}\text { Trapezoidal } 1.5 \mathrm{H} \times 1 \mathrm{~V} \text { except rectangular }{ }^{*} \\
\text { for stretches covered by sound rocks }\end{array}$ & $42.7 \mathrm{~km}$ & 1007.3 \\
\hline
\end{tabular}

${ }^{*}$ Canal stretches of permeable soil formation; geo-membrane lining with a protection of boulders covered with geo-mesh was adopted. ${ }^{*}$ The particularity of this part of the canal is that, it was constructed to serve as storage by widening the canal section and providing head regulating weir at the end.

\subsection{Data Analysis}

Irrigation water is normally conveyed from a water source to the farm or field through natural drainage ways, constructed earthen or lined canals, or pipelines. Many conveyance systems have transmission losses, meaning that water delivered to the farm or field is usually less than the water diverted from the source. Water losses in the conveyance system include canal seepage, canal spills, evaporation losses from canals, and leaks in pipelines. These losses have to be taken into account when calculating the gross irrigation requirements of an irrigation project. This can be done through the use of an efficiency factor called conveyance efficiency, which has to be estimated at the planning stage. The higher the conveyance efficiency, the lesser the water loss, thus the larger the area that can be irrigated from a given finite water source, and the less the leaching of nutrients and damage to the soil and the more environmentally friendly the irrigation system will become. Canal conveyance efficiency, for the purpose of this study being defined as the ratio of the volume of water delivered at the downstream end to the volume of water released at the upstream end of the canal section, can be derived by the use of the following equation [2]:

$$
E c=\frac{V_{d}+V_{2}}{V_{c}+V_{1}} \times 100
$$

where

$E c$ = conveyance efficiency;

$V_{c}=$ volume of water at upstream canal end $\left(\mathrm{m}^{3}\right)$;

$V_{1}=$ inflow, if any, from other sources within the section $\left(\mathrm{m}^{3}\right)$;

$V_{d}=$ volume of water delivered to the farmer (at the downstream end of the section) $\left(\mathrm{m}^{3}\right)$;

$V_{2}=$ non-irrigation deliveries from the conveyance system $\left(\mathrm{m}^{3}\right)$.

Conveyance efficiency could also be analyzed on the basis of measured discharge data, which is the volume of water per unit time. In this study discharge was measured at different locations over the length of the canal in order to calculate the $E c_{i}$ at different sections. The overall conveyance efficiency of the canal is then the product of $E c_{i}$ calculated at different sections over the length of the canal.

Many factors affect the conveyance efficiency of a canal, among which, hydraulic and hydrologic causes are presented in this paper. To evaluate the effect of change in the conveyance efficiency the study and design documents of Fentale irrigation scheme was thoroughly assessed. The study and design documents of the project have used manning equation for canal design. This is acceptable, as the canals could be treated as uni- 
form flow where in manning's equation is popular [12] [13] [14] [15]. In using the manning's equation for conveyance efficiency evaluation, conveyance parameters like manning's roughness coefficient, canal slope and canal hydraulic radius were scrutinized. Thus observed values of manning's roughness coefficient, wetted perimeter and bed slope shall be compared with the designed values. Observed values of these conveyance characters were obtained through careful measurement of velocity, canal slope, wetted area and wetted perimeters of the canal at different locations and use these in manning equation for manning's roughness coefficient estimation as follows [16].

$$
Q=\frac{1}{n} S^{1 / 2} A R^{2 / 3} \Rightarrow n=\frac{S^{1 / 2} A R^{2 / 3}}{Q}
$$

where,

$Q$ is discharge of the canal $\left(\mathrm{m}^{3} / \mathrm{s}\right)$ - Measured in a field;

$R=(\mathrm{A} / \mathrm{P})$ is Hydraulic radius $(\mathrm{m})-$ Computed from field observed values;

$A=$ Wetted cross-sectional area $\left(\mathrm{m}^{2}\right)$ - Surveyed in filed;

$P=$ Wetted perimeter $(\mathrm{m})$ - Surveyed in field;

$S=$ bed slope (-) - Surveyed in field;

$n=$ Manning's roughness coefficient (-) - Computed from field observed values.

In evaluating the hydrologic effects, the resulting canal dimension change effect on the possible hydrologic water loss reason were analyzed. Thus the possible evaporation and seepage loss along the canal length is evaluated and compared with the expected (designed) one.

\section{Results and Discussions}

The first reconnaissance study to the site has consulted the potential stakeholders of Fenatale irrigation scheme (District Agricultural office, Irrigation Water users Association, and Oromia irrigation development authority). From the consultation, in addition to the canal cross section near by the head regulator, it was decided to observe canal discharges at three different locations along the main canal. The same consultation is used to decide the time and location on which non-irrigation delivery along these canals is minimal ( $V_{2}$ in Equation (1) is zero). Besides the main canal do not have any other inflow along the reach selected ( $V_{1}$ in Equation (1) is zero). Accordingly the data were collected during such defined time and locations. The locations of the measurements are shown in Table 2.

Fentale was designed and constructed to take maximum of $18 \mathrm{~m}^{3} / \mathrm{sec}$ of water from the river by Diversion Weir. The main canal off taking from the diversion weir and serving the command area was designed and constructed for 24-hour continuous flow [9]. Nevertheless, during site observation (January, 2013), the discharge released from the weir was measured to be $4.513 \mathrm{~m}^{3} / \mathrm{s}$ and the total command area developed was estimated to be 8000 ha.

The four locations naming, design capacity and observed discharges during field study were shown in Table 2 and the observed canal section profile with the corresponding velocity is depicted in Figures 2-5 below in which the scale bars show the velocity in $\mathrm{m} / \mathrm{s}$ unit. For better depiction of the flow velocity, Figure 4 and Figure 5 are drawn by making the scale in the depth direction exaggerated. 


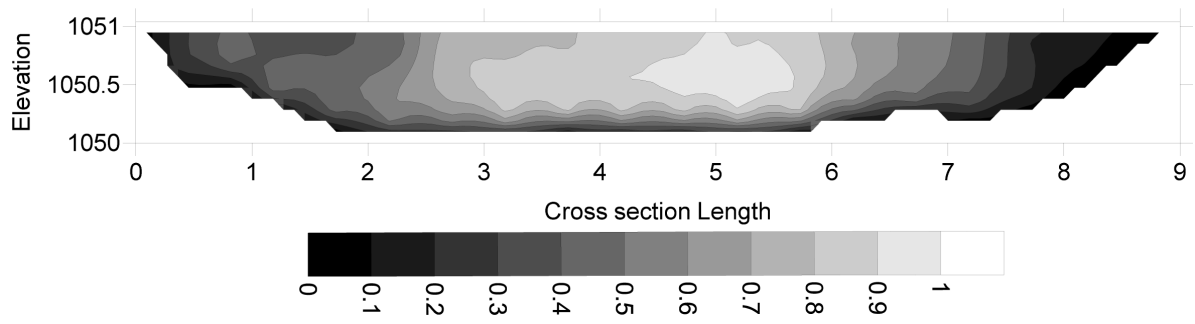

Figure 2. Observed canal section and velocity distribution at head regulator.

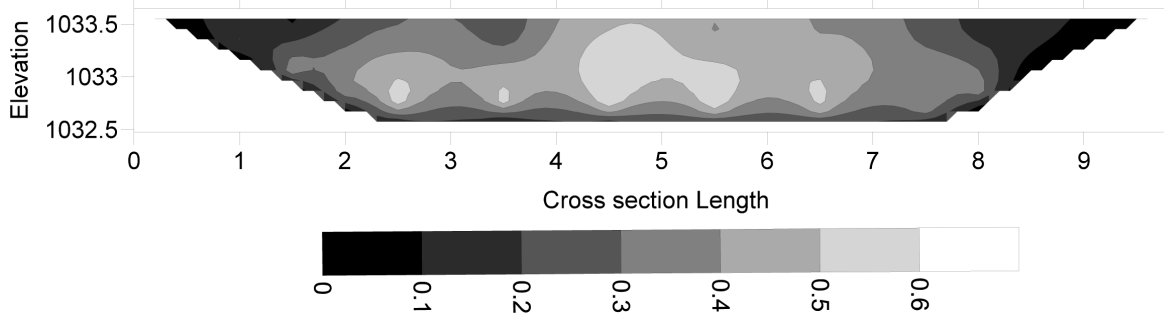

Figure 3. Observed canal section and velocity distribution at $17.52 \mathrm{~km}$.

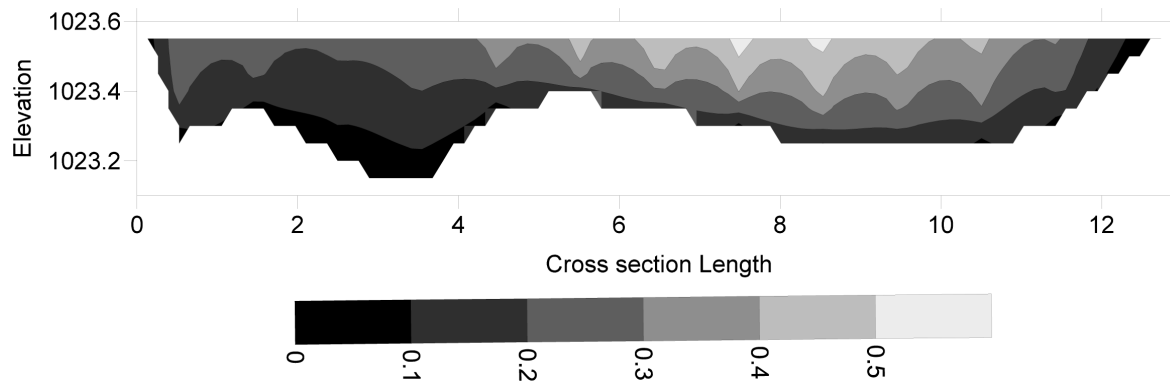

Figure 4. Observed canal section and velocity distribution at $26.9 \mathrm{~km}$.

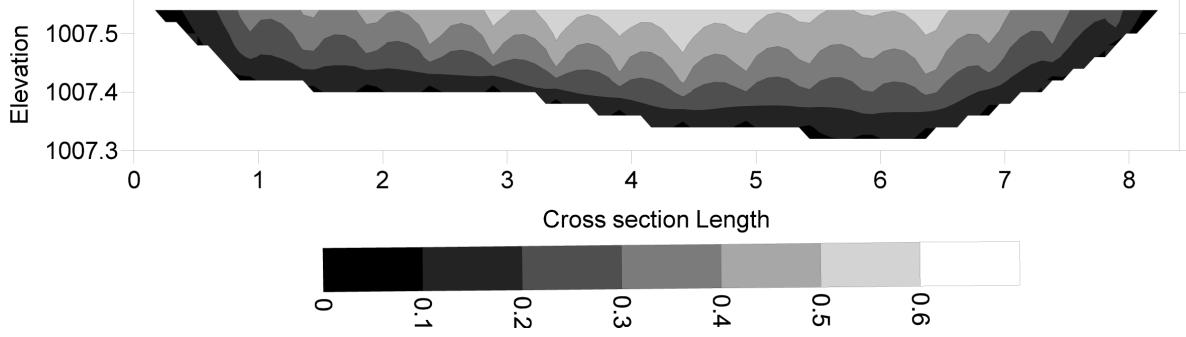

Figure 5. Observed canal section and velocity distribution at $42.7 \mathrm{~km}$.

\section{Conveyance Parameters}

Hydraulic parameters variation from what has been estimated during design has a great effect on the conveyance efficiency $(\mathrm{Ec})$ of canals. The conveyance parameters variation is seen by carefully analyzing the manning's roughness coefficient, wetted perimeter of the canal and top width of the canal water surface. The values of the existing manning's roughness coefficient for different sections along the main canal were between 0.026 0.073 (see Table 3); however, at the same locations the designed values range from $0.017-0.03$. The increase in the value of roughness coefficient is mainly due to the canal section material change which ultimately decreases the discharge carrying capacity of the canal. 
Table 3. Conveyance parameters at the four sections along the main canal.

\begin{tabular}{|c|c|c|c|c|c|c|}
\hline Location at & S Bed slope* & $A\left(m^{2}\right)^{\star}$ & $\mathrm{P}(\mathrm{m})^{*}$ & $\mathrm{R}(\mathrm{m})(\mathrm{A} / \mathrm{P})$ & $\mathrm{Q}\left(\mathrm{m}^{3} / \mathrm{s}\right)^{*}$ & Manning's ${ }^{* *}$ \\
\hline HR & 0.0012 & 7.409 & 9.682 & 0.636 & 4.351 & 0.049 \\
\hline $17.525 \mathrm{~km}$ & 0.001 & 8.706 & 10.428 & 0.683 & 3.355 & 0.073 \\
\hline $26.9 \mathrm{~km}$ & 0.001 & 4.118 & 13.201 & 0.29 & 1.239 & 0.048 \\
\hline $42.7 \mathrm{~km}$ & 0.001 & 1.445 & 8.431 & 0.16 & 0.536 & 0.026 \\
\hline
\end{tabular}

${ }^{*}$ Measured at field level. ${ }^{*}$ Computed by making use of Equation (2).

The conveyance efficiency of the main canal is also compared in Table 1 for the existing and designed condition. Conveyance efficiency is affected by several factors among which are size irrigated area, size of rotational unit, number and types of crops grown, type conveyance system and the technical and managerial facilities for water control [14]. Conveyance efficiency could be as high as 0.9 , if continuous supply with no substantial change in flow occur. According to Food and Agricultural Organization of the united nations (FAO) [14] the lower limit for conveyance efficiency is 0.65 , which presumed to exist if rotational supply in large schemes (>10,000 ha) and small schemes $(<1000$ ha) with respective problematic communication and less effective management.

The design Ec value for Fentale Irrigation project is within the recommended range, as far as the FAO recommendations are accepted. However, the existing conveyance efficiency could not add up to the expectations. The low efficiency indicates possible assumption errors in the design or construction of infrastructure. This variation complicates operation and maintenance of the irrigation system. The difference between the planned and actual efficiency is partly due to a too optimistic estimate of the post-construction efficiency the main canal.

It could be seen here that the values of Ec are by far different from one another. The decrease in efficiency is larger in the main canal reach after the $17.52 \mathrm{~km}$ length. This is mainly due to high silt deposition and wide coverage of the canal section with grass and weed as observed during the field survey.

To evaluate the possible water loss through seepage and evaporation due to the altered conveyance parameters, the wetted perimeter and top width variation of the canal were also computed for the design discharges by taking the bed width and side slopes of the design parameters. Accordingly Table 4 shows the results, from the table it is possible to deduce that the design dimensions will no longer carry the discharges, which exacerbate the seepage and the evaporation losses. The same table show that the design water depth has increased by $0.66 \mathrm{~m}, 0.43 \mathrm{~m}, 0.47 \mathrm{~m}$, and $0.41 \mathrm{~m}$ at the head regulator at $17.52 \mathrm{~km}$, at $26.9 \mathrm{~km}$ and at $42.7 \mathrm{~km}$, respectively. This increase in water level will bring about overflow of canal water which is again another cause for conveyance Efficiency variation.

\section{Conclusions}

The expected (designed) and the actual value of conveyance parameters obtained for the main canal of Fentale irrigation scheme show great difference; $77 \%$ during design against the $17 \%$ existing conveyance efficiency obtained during the study time. Such 
Table 4. Top width (TW) and wetted parameter (P) increase on the main canal.

\begin{tabular}{ccccccccccc}
\hline \multirow{2}{*}{ Location } & \multirow{2}{*}{ Design Q } & \multicolumn{4}{c}{ Existing } & \multicolumn{3}{c}{ Designed } & \multicolumn{3}{c}{ \% increase } \\
\cline { 3 - 11 } & & Slope & $\mathrm{y}(\mathrm{m})$ & TW $(\mathrm{m})$ & $\mathrm{P}(\mathrm{m})$ & $\mathrm{y}(\mathrm{m})$ & $\mathrm{TW}(\mathrm{m})$ & $\mathrm{P}(\mathrm{m})$ & $\mathrm{TW}$ & $\mathrm{P}$ \\
\hline $\mathrm{HR}$ & 18 & 0.0012 & 1.79 & 10.2 & 15.5 & 1.13 & 9.7 & 13.1 & 5 & 18 \\
$17.52 \mathrm{~km}$ & 17 & 0.001 & 1.65 & 11.0 & 15.9 & 1.22 & 10.7 & 14.3 & 3 & 11 \\
$26.9 \mathrm{~km}$ & 15 & 0.001 & 1.33 & 13.9 & 17.8 & 0.86 & 13.6 & 16.1 & 2 & 10 \\
$42.7 \mathrm{~km}$ & 7.2 & 0.001 & 1.1 & 9.13 & 12.4 & 0.69 & 8.86 & 10.9 & 3 & 14 \\
& \multicolumn{3}{c}{ Average increase in percent } & & & & 3 & 13 \\
\hline
\end{tabular}

huge variation in conveyance efficiency resulted from variation in the hydraulic parameters like manning's roughness coefficient and canal slope; the former being the main contributor to the decrease in conveyance efficiency. Such variation will result in 42 $66 \mathrm{~cm}$ water level rise, if the canal is expected to carry the design discharge. This rise in the water level has resulted in $3 \%$ increase in the top width of the canal water surface and $13 \%$ increase in wetted perimeter across the canal section. This in turn results in loses like evaporation from the top water surface and seepage through the increased wetted perimeter. Besides the increase in water depth could bring about over bank flow along the main canal section.

Such differences are basically either be improper conveyance parameter estimation during design and planning phase or improper operation and maintenance of the canal. The study clearly shows that, irrespective of the cause, there is a lot of water which is lost in the main canal. This is also true for other canal systems (secondary and lower order canals) which were not seen in this study, which makes the total loss a much larger threat to the overall benefit of the project. Thus this study suggests that conveyance parameters shall be derived from experience of existing irrigation systems, rather than adopting it from standard literatures. As such construction quality and maintenance activities shall be seen in deciding the conveyance efficiency estimation. The study also suggests that the ever increasing water shortage in an irrigation project could be managed by proper maintenance of the entire irrigation system.

\section{Acknowledgements}

The authors are grateful to Addis Ababa Institute of technology, Federal Policy study and research center for their strong support of the research publication. We would also like to acknowledge Ministry of water irrigation and Electricity for giving us the current meter for the discharge measurement. Last but not least the authors are grateful to the anonymous reviewers for their valuable comments that improve this publication.

\section{References}

[1] McCornic, P.G., Kamara, A.B. and Tadesse, G. (2003) Integrated Water and Land Research and Capacity Building Priorities for Ethiopia.

[2] Bos, M.G. and Nugteren, J. (1990) On Irrigation Efficiencies. ILRI Publication.

[3] Abdu, B. and Bekele, S. (2007) Analysis of Irrigation Systems Using Comparative Performance Indicators: A Case Study of Two Large-Scale Irrigation Systems in the Upper Awash Basin. International Water Management Institute, Addis Ababa. 
[4] Yesuf, K. (2004) Assessment of Small-Scale Irrigation Using Comparative Performance Indicators on Two Selected Schemes in Upper Awash River Valley. Unpublished MSc Thesis, Alemaya University.

[5] OWWDSE (2009) Fentale Irrigation Based Integrated Project: Socioeconomic Study. Unpublished, Finfinne.

[6] Badenhorst, J.W., De Lange, M., Mokwena, M.E. and Rutherford, R.J. (2002) Water Conservation and Water Demand Management in Agriculture: Development of Water Management Plans by Irrigation Water Suppliers in South Africa. ICID Eighteenth Congress Best Paper for 6 th Hassan Ismail A ward Paper, Montreal.

[7] Xie, M., Kuffner, U. and Le Moigne, G. (1993) Using Water Efficiently: Technological Options. World Bank Technical Paper Number 205, Washington DC.

[8] Australian National Committee on Irrigation and Drainage (ANCID) (2000) Open Channel Seepage and Control-Literature Review of Channel Seepage Identification and Measurement. Vol. 1.1, Victoria, Australia.

[9] OWWDSE (2009) Fentale Irrigation Based Integrated Project: Engineering Report. Unpublished, Fifinne.

[10] OWWDSE and Synergics Hydro (India) (2009) Fentale Irrigation Scheme Operation and Management Study Report. Unpublished, Finfinne.

[11] Turnipseed, D.P. and Sauer, V.B. (2010) Discharge Measurements at Gaging Stations. USGS, Virginia.

[12] Michael, A.M. (2009) Irrigation Theory and Practice. Vikas Publication House, New Delhi.

[13] Bos, M.G., Wolters, W., Drovandi, A. and Morabito, J.A. (1991) The Viejo Retamo Secondary Canal-Performance Evaluation (Case Study). Irrigation and Draniage Systems, Mendiza.

[14] Food and Agricultural Organization of the United Nations (FAO) (1992) Irrigation Scheme Operation and Maintenance: Irrigation Water Management. Manual No. 10, Rome.

[15] FAO (1989) Guidelines for Designing and Evaluating Surface Irrigation Systems. Irrigation and Drainage Paper No. 45.

[16] VenTe Chow (1959) Open-Channel Hydraulics. McGraw-Hill, New York.

\section{Submit or recommend next manuscript to SCIRP and we will provide best service for you:}

Accepting pre-submission inquiries through Email, Facebook, LinkedIn, Twitter, etc.

A wide selection of journals (inclusive of 9 subjects, more than 200 journals)

Providing 24-hour high-quality service

User-friendly online submission system

Fair and swift peer-review system

Efficient typesetting and proofreading procedure

Display of the result of downloads and visits, as well as the number of cited articles

Maximum dissemination of your research work

Submit your manuscript at: http://papersubmission.scirp.org/

Or contact cweee@scirp.org 